\title{
KIINNOSTAAKO NOSTE-KOULUTUS SEN KOHTEENA OLEVIA IHMISIÄ?
}

\begin{abstract}
Aikuisten puolesta ei voida päättää mitä koulutusta he tarvitsevat, vaan koulutuksen tarpeen on lähdettävä aikuisista itsestään. Suunnittelu- ja valmisteluasiakirjoissa Noste-ohjelman kohdejoukosta puhutaan laskennallisena ja varsin yhtenäisenä 330000 ihmisen ryhmänä. AKU2000-aineiston valossa kohdejoukko näyttää hyvin heterogeeniseltä ja monenlaisia koulutuskokemuksia omaavalta ryhmältä, jota yhdistää muodollisen tutkinnon puuttuminen.
\end{abstract}

\section{HANNE KOKKILA}

$\mathrm{V}$ altioneuvosto antoi Parlamentaarisen aikuiskoulutustyöryhmän (PAT) mietinnön pohjalta asetuksen aikuisten koulutustason kohottamiseen myönnettävästä valtionavustuksesta (A41/2003), jonka perusteella opetusministeriö toteuttaa koulutustason kohottamiseen tähtäävää Noste-ohjelmaa vuosina 2003-2007. Noste-ohjelman tarkoituksena on parantaa enintään perusasteen tutkinnon suorittaneiden työelämässä pysymistä ja urakehitystä, lieventää suurten ikäluokkien eläkkeelle siirtymisestä johtuvaa työvoimapulaa sekä vaikuttaa positiivisesti työllisyysasteeseen. (Opetusministeriö 2002; 2003a; 2003b.)

Uusi asetus (A35/2004) astui voimaan helmikuun alussa. Näkyvin muutos entiseen asetukseen verrattuna on kohderyhmän yläikärajan kohottaminen 54-vuodesta 59-ikävuoteen. Uudistuksen jälkeen asetuksen sisältö on samassa linjassa hallituksen tavoitteiden kanssa pidentää työelämässä jaksamista ja myöhentää eläkeikää (Opetus-ministeriö 2004).

Noste-ohjelma rakentuu elinikäisen oppimisen periaatteelle. Esimerkkinä koulutustason kohottamisohjelman suunnittelussa on toiminut Ruotsissa toteutettu Kunskapslyftet (the Swedish Adult Education Initiative) (esim. Rubenson 2001). Noste-ohjelman perustelut liittyvät myös yhteiskunnalliseen ja koulutukselliseen eriarvoisuuteen. Suomalainen koulutusjärjestelmä on osoittautunut kansainvälisissä vertailuissa tasaarvoisemmaksi, ja vähemmän eriarvoistavaksi kuin useimpien muiden maiden koulutusjärjestel- mät. Aikuiskoulutus on kuitenkin tästä poikkeus. (OECD \& Statistics Canada 2000; Antikainen 2003a.) Aikuisten osallistumi-nen koulutukseen vaihtelee Suomessa koulutusasteittain, ja aikaisempien tutkimusten perusteella on todettu, että osallistumisaktiivisuus on sitä suurempi, mitä pidempi on vastaajan pohjakoulutus (Blomqvist, Ruuskanen, Niemi \& Nyyssönen 2002; Moore 2002; Silvennoinen \& Aaltonen 1999; Blom-

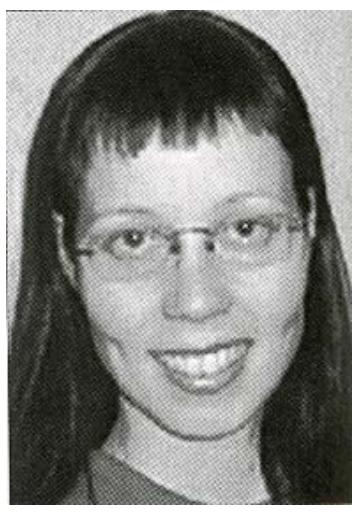

Hanne Kokkila qvist, Koskinen, Niemi \& Simpanen 1997).

Aikuiskoulutukseen osallistumisen erot ovat Suomessa pohjoismaisen vertailun mukaan Pohjoismaiden suurimmat ja OECD:n arvion mukaan ne ylittävät kehittyneiden maiden keskitason (OECD \& Statistics Canada 2000; Tuijnman \& Hellström 2001). Tästä näkökulmasta Noste-ohjelma on kolmikantainen valtiollinen interventio koulutukseen osallistumiseen ja koulutuksen avulla saavutettavien hyötyjen jakamiseen (Antikainen 2003b).

Tarkasteluni kohteena tässä on vuoden 2003 asetuksen (A41/2003) mukainen Noste-ohjelman ensisijainen kohderyhmä eli 30-54-vuotiaat enintään perusasteen tutkinnon suorittaneet työlliseen työvoimaan kuuluvat aikuiset. ${ }^{1}$ Tavoitteenani on luoda kuva Noste-ohjelman kohderyhmästä ohjelman suunnittelu- ja valmisteluasiakir- 
jojen (Opetusministeriö 2002; 2003b; 2004) ja Aikuiskoulutustutkimus 2000 (AKU2000)-aineiston pohjalta. ${ }^{2}$ Kohderyhmän näkemyksiä koulutuksesta käsitellään AKU2000 -aineiston aikuiskoulutusta koskevien kysymysten, kuten aikaisempien opintojen, koulutukseen osallistumisen, osallistumis-aikomusten ja koulutukseen asennoitumisen kautta. Kohderyhmän rakenteeseen, osallistumisen malleihin ja osallistumis-aikomuksiin liittyviä erityispiirteitä havainnollistetaan lisäksi vertaamalla kohderyhmää korkeammin koulutettuihin.

\section{AIKUISKOULUTUSTUTKIMUS 2000 -AINEISTO}

Artikkelin aineistona on Aikuiskoulutustutkimus 2000-aineisto, joka koostuu 3422 iältään 18-64vuotiaan henkilön haastattelusta. Haastatelluista henkilöistä 60 prosenttia (n=2041) oli haastatteluhetkellä 30-54-vuotiaita. Noste-ohjelman kohderyhmään kuului 22 prosenttia $(n=446)$ aineiston 30-54-vuotiaista, mikä vastaa väkilukuun suhteutettuna suunnilleen puolta miljoonaa suomalaista.

AKU2000 -aineiston ja muiden vastaavien tilastojen tuottaminen perustuu oletukseen koko väestöä koskevasta yhtenäiskulttuurista, jossa kaikkia väestönosia voidaan kuvata samoilla käsitteillä (Kurkela \& Sauli 1998, 37). Aikuiskoulutustutkimukseen osallistuneet henkilöt vastaavatkin suhteellisen hyvin perusjoukkoa eli 18-64vuotiaita suomalaisia. Nyky-yhteiskunnan voi kuitenkin ajatella muodostuvan myös erilaisista osakulttuureista yhtenäiskulttuurin sijaan (Bourdieu 1997, 4). AKU2000 -aineisto näyttää katoanalyysin perusteella kertovan osakulttuureista yhte-näiskulttuurin sijaan, sillä kato painottuu eri ryhmissä eri tavoin. Noste-ohjelman kohderyhmä kuuluu siihen joukkoon, jossa katoa esiintyi eniten. ${ }^{3}$ Enintään perusasteen tutkinnon suorittaneista lähes kolmannes kieltäytyi, jäi tavoittamatta tai muuten haastattelematta. (Blomqvist, Ruuskanen, Niemi \& Nyyssönen 2002, 126, 131132.) Koulutustason mukaan tarkasteltuna kohderyhmän aikuiset osallistuivat AKU2000 -haastatteluihin selvästi harvemmin kuin korkea-asteen tutkinnon suorittaneet. Myös aikaisemmissa tutkimuksissa lyhyemmän pohjakoulutuksen omaavat ovat olleet pidempään kouluttautuneita haluttomampia osallistumaan tutkimuksiin (esim. Blomqvist, Ruuskanen, Niemi \& Nyyssönen
2002; Blomqvist, Koskinen, Niemi \& Simpanen 1997). Aineiston tuloksia voidaan kuitenkin pitää luotettavina, koska vinoutumat on korjattu painokertoimien avulla. Koulutustaustan mukaiset erot vastaushalukkuudessa ovat kuitenkin itsessään mielenkiintoisia, vaikka niillä ei ole suoranaista vaikutusta tutkimuksen tulosten luotettavuudelle.

Kurkela ja Sauli (1998) ovat verranneet yhteiskuntaa ja ihmisten elämää kuvaavien survey-tutkimusten suhdetta elokuvan studiolavasteisiin. Survey-tutkimusten käsitteet ja luokitukset vastaavat rakennettuja lavasteita, joiden puitteissa arkielämää kuvataan ja tulkitaan. Häiriötekijät minimoidaan tilastollisilla käsitteillä lavastetussa todellisuuskuvassa ja kuvauksen kannalta tarpeettomia yksityiskohtia vähennetään, mutta samalla perspektiivi ja koko kuva muuttuvat. Kun arkielämä kaikessa moninaisuudessaan puristetaan yhteen ja samaan yleiseen luokitukseen, kuva arjesta normalisoituu. Tutkiessani Nosteohjelman kohderyhmän koulutukseen osallistumista kuva koulutukseen osallistumisen syistä ja seurauksista, eduista ja esteistä kapenee, kun eri yksilöiden elämäntilanteet sovitetaan valmiiksi annettuihin vastausvaihtoehtoihin. Toisaalta tilastolliset tutkimukset hajottavat elämän erillisiksi muuttujiksi. Valmiisiin luokituksiin sopeutumattomia olosuhteita esiintyy tilastollisesti vähän ja tapaukset tilastoidaan useimmiten luokaan "muut". Niiden aineistosta poisjättäminen muuttaa ja kaventaa havaittua todellisuutta. Tästä johtuu, ettei uusia ilmiöitä näy tilastoissa ennen kuin ne on nostettu esille luokasta "muut" ja nimetty uudelleen. Uusien ilmiöiden nimeäminen ja luokittelu rikkoo kuitenkin jatkuvuuden, vertailtavuuden ja yhtenäisyyden periaatteita, joita AKU:n kaltaisilla seurantatutkimuksilla tavoitellaan. (Kurkela \& Sauli 1998.) Vuoden 2000 Aikuiskoulutustutkimus on järjestyksessään viides aikuisten kouluttautumista koskeva tutkimus. Aikaisempien AKU -aineistojen lisäksi kansainväliset koulutustutkimukset ovat määrittämässä sitä, mitä tutkimuksessa kysytään ja miten vastaukset luokitellaan.

AKU2000 -aineistoa on käsitelty SPSS -ohjelmalla, ja muuttujien välisiä suhteita on artikkelissa kuvattu enimmäkseen ristiintaulukoimalla. Ristiintaulukoinnin yhteydessä on selvitetty Pearsonin Khiin neliötestin (?²) avulla muuttujien välistä tilastollista riippuvuutta. Testissä on käytet- 
ty $5 \%$ :n merkitsevyystasoa. Artikkelissa ?²-testi on tehty tutkimusjoukolle (n) korottamatta tuloksia painokertoimen avulla väestötasolle (N), koska muuttujien välinen riippuvuus on todennäköisesti merkitsevää, mikäli otoskoko on suuri (Walsh 1990, 204).

\section{NOSTE-OHJELMAN \\ KOHDERYHMÄ}

Aikuisten koulutustason kohottamisohjelman kohdejoukon määrittely on vaihdellut hankkeen edetessä. Parlamentaarisen aikuiskoulutustyöryhmän mietinnön kuvailulehdillä kerrotaan ohjelman kohteen olevan "aktiivinen aikuisväestö, jolla ei ole toisen asteen tutkintoa”. Ohjelman kohderyhmäksi määritellään tekstiosuuden alussa "30-54-vuotiaat vailla toisen asteen tutkintoa olevat kansalaiset”. Myöhemmin tekstissä koulutustason nostamiseksi suunnitellun ohjelman kohdejoukoksi mainitaan "vailla toisen asteen tutkintoa olevat 30-54-vuotiaat työlliseen työvoimaan kuuluvat”, eli palkansaajat, yrittäjät ja maatalousyrittäjät. (Opetusministeriö 2002, 9, 16-18.)

Parlamentaarisen aikuiskoulutustyöryhmän mietinnössä kohderyhmän rajausta enintään perusasteen tutkinnon suorittaneisiin perustellaan työmarkkinatilanteella. Mietinnön mukaan aikuiset, joilta puuttuu toisen asteen koulutus, ovat työelämän kannalta kaikkein vaikeimmassa asemassa. Noste-ohjelman tulisikin mietinnön mukaan turvata näille ryhmille mahdollisuus kohottaa tai päivittää koulutustasonsa työmarkkinoiden kehitystä vastaavaksi siten, että koulutusajat pysyisivät kohtuullisina, eikä liian pitkä oppilaitosmuotoinen koulutus olisi este koulutukseen hakeutumiselle. Toisaalta myös ne aikuiset, joilta puuttuvat riittävät tietoyhteiskuntavalmiudet työelämässä pärjäämiseen ja aktiivisena kansalaisena toimimiseen kuuluvat mietinnön mukaan työelämän kannalta riskiryhmään. Näille aikuisille tulee turvata mahdollisuudet tietoyhteiskunnan perustaitojen omaksumiseen. (Opetusministeriö 2002, 16.)

Valtioneuvoston asetuksessa Parlamentaarisen aikuiskoulutustyöryhmän ehdotus koulutustason nostamisesta on muuttunut koulutustason kohottamiseksi, ja Nosto-ohjelma Noste-ohjelmaksi. Vuonna 2003 annetun asetuksen mukaan ohjelma kohdistetaan ensisijaisesti työssä oleville, enintään perusasteen tutkinnon suorittaneille 30-54-vuotiaille (A41/2003). Uudessa asetukses- sa kohderyhmän yläikärajaa on nostettu 59-vuoteen, ja sanat "ensisijaisesti työssä oleville" on muutettu muotoon "pääasiallisesti työssä oleville” (A35/2004). Mietinnössä esitettyihin työllisyyttä korostaviin tavoitteisiin pyritään Nosteohjelmassa suosimalla toisen asteen ammatillisia tutkintoja, joita suoritetaan pääosin aikuisten ammatillisen näyttötutkintojärjestelmän avulla. Aikuisten tietoyhteiskuntavalmiuksista Noste pyrkii huolehtimaan ohjelman puitteissa rahoitetuilla tietokoneen ajokorttitutkinnoilla. Nosteohjelman todetaan olevan avoin myös työttömille. Työministeriön alalla erillisrahoitusta ohjelmaan ole käytössä, vaan aikuisten koulutustason kohottamisohjelmaa toteutetaan olemassa olevia palveluita ja resursseja suuntaamalla. (Opetusministeriö 2002; 2003b; 2004.)

\section{Vailla toisen asteen tutkintoa?}

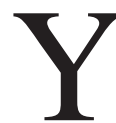

hteistä Noste-ohjelman valmisteluasiakirjoissa esiintyneille kohdejoukon määrittelyille on vaatimus enintään perusasteen tutkinnosta. Noste-ohjelman luonnoksessa todetaan, että tulkinta perusasteen jälkeisen tutkinnon suorittamisesta etenkin ammatillisen peruskoulutuksen osalta tulisi olla väljää, koska ammatillisen koulutuksen tuottama tutkintokelpoisuus on vaihdellut ajan saatossa. (Opetusministeriö 2003b). Tutkintojen tulkinnanvaraisuus tulee esiin myös AKU2000 -aineistossa, sillä oman koulutustason määrittämisessä oli ongelmia riippumatta vastaajan koulutusasteesta. Tutkintorekisterin mukaan vailla toisen asteen tutkintoa olevista joka viides kertoi haastatteluissa suorittaneensa vähintään toisen asteen tutkinnon. Useimmat heistä kertoivat suorittaneensa kouluasteen ammatillisen tutkinnon. Tutkintorekisterin mukaan keskiasteen tutkinnon suorittaneista 10 prosenttia ei omasta mielestään ollut suorittanut toisen asteen tutkintoa, eli lukiota, ylioppilas- tai ammatillista tutkintoa, mutta 11 prosenttia ilmoitti itse suorittaneensa korkea-asteen tutkinnon. Tutkintorekisterissä korkea-asteen tutkinnon suorittaneiksi luokitelluista henkilöistä puolestaan 5 prosenttia ilmoitti itse korkeimmaksi tutkinnokseen kouluasteen ammatillisen tutkinnon. Tutkintorekisterin ja vastaajien itse ilmoittamien tietojen ristiriitaa esiintyy myös aikaisemmissa AKU -aineistoissa (esim. Simpanen 1993).

Tutkintojen hankalan määrittelyn taustalla saattaa olla tutkinnon käsitteen ja tutkintorekis- 


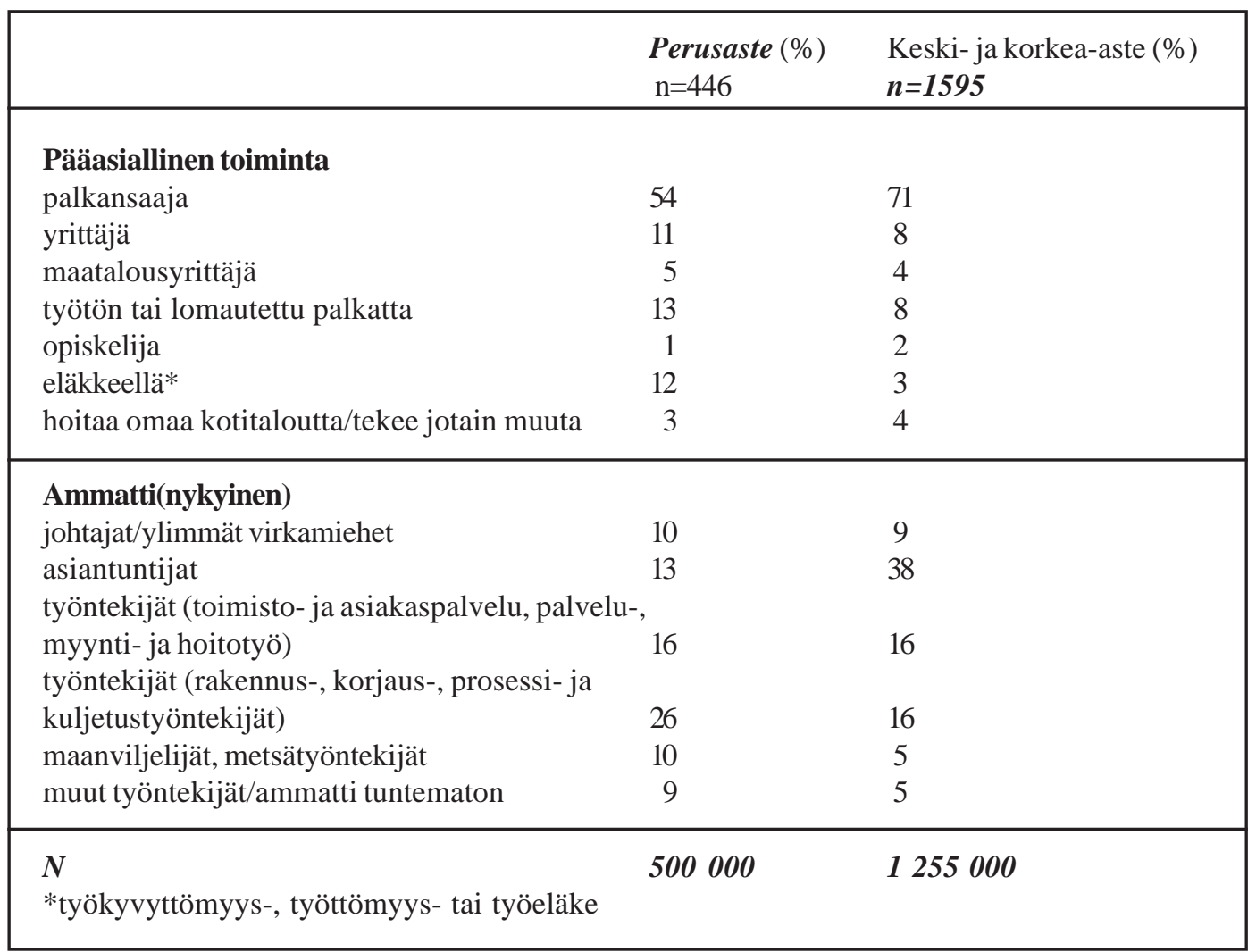

terin sisällön täsmentyminen vuosien kuluessa, sillä mikään yksittäinen tekijä (kuten ammattiala, ulkomailla suoritetut opinnot tai opintojen kesto) ei selittänyt kattavasti eroja vastaajien itse ilmoittaman tutkinnon ja tutkintorekisterin tietojen välillä. ${ }^{4}$ Edellä esitetyistä tulkintavaikeuksista johtuen artikkelissa päädyttiin käyttämään tutkintorekisterin tietoja. Esimerkiksi Tilastokeskus käyttää tutkintorekisterin tietoja koulutusasteluokituksen perusteena ja tutkijat puolestaan hyödyntävät Tilastokeskuksen aineistoja. Määrittelen tässä yhteydessä vailla toisen asteen tutkintoa oleviksi ne henkilöt, joilla ei tutkintorekisterin mukaan ole toisen asteen tutkintoa.

Tutkintorekisteritietojen perusteella Nosteohjelman kohderyhmään kuuluvia 30-54-vuotiaita, enintään perusasteen tutkinnon suorittaneita työlliseen työvoimaan kuuluvia henkilöitä on Suomessa noin 350 000. Kun Noste-ohjelman kohderyhmään kuuluviksi lasketaan kaikki ne AKU2000 -aineiston 30-54-vuotiaat työelämässä mukana olevat henkilöt, jotka oman ilmoituksensa mukaan ovat vailla toisen asteen tutkintoa, saadaan painokertoimen avulla lukumääräksi 335000 henkilöä. Noste-ohjelmaa käsittelevis- sä teksteissä (esim. Ahola 2002) kohderyhmään kuuluvien lukumääräksi ilmoitetaan usein 330000 henkilöä.

\section{Heterogeeninen joukko}

Aikuiskoulutustutkimus 2000 -aineiston 30-54vuotiaita Noste-ohjelman kohdejoukkoon kuuluvia ja keski- tai korkea-asteen tutkinnon suorittaneita verrataan toisiinsa pääasiallisen toiminnan ja nykyisen ammatin suhteen taulukossa 1 . Koulutustasosta riippumatta enemmistö vastaajista on palkansaajia. Perusasteen tutkinnon suorittaneista noin joka toinen on palkansaaja, ja korkeammin koulutetuista vieläkin useampi (71 \%). Perusasteen tutkinnon omaavia palkansaajia työllistää eniten yksityinen sektori (68 \%), ja se työllistää enemmän miehiä (74 \%) kuin naisia (64 \%). Samoin valtio on työnantajana useammin miehillä (13\%) kuin naisilla (9 \%). Sen sijaan kuntasektori työllistää selvästi enemmän Noste-ohjelman kohdejoukon naisia: kunnan palveluksessa on neljäsosa naisista ja kymmenesosa miehistä. Lähes kaikkien palkansaajien työsuhde on laadultaan pysyvä; ainoastaan 7 prosenttia on määräaikai- 
sessa työsuhteessa. Työsuhde on määräaikainen huomattavasti yleisemmin naisilla kuin miehillä. Noste-ohjelman kohderyhmään kuuluvat tekevät pääosin (95 \%) kokoaikatyötä. Kuten määräaikaisina, myös osa-aikaisina työskentelee useampi naisista.

Nosteen kohderyhmässä on viisi prosenttiyksikköä enemmän työttömiä verrattuna korkeammin koulutettuihin. Kohdejoukon miesten ja naisten työttömyydessä ei ole eroa. Ennen työttömyyttä lähes kaikki ovat olleet mukana työelämässä (92 \%) pääasiassa palkansaajina (85 \%). Kohderyhmän työelämässä pysyminen mainitaan myös Noste-ohjelman tavoitteissa. Enintään perusasteen tutkinnon suorittaneista useampi kuin joka kymmenes on eläkkeellä, ja ero korkeammin koulutettuihin on selkeä. Toisaalta vailla toisen asteen tutkintoa olevien ryhmään kuuluu myös henkilöitä, joilla sairaus tai vamma on ollut jo lähtökohtaisesti estämässä opiskelua.

Perusasteen tutkinnon suorittaneiden ammattirakenne on hyvin monipuolinen (taulukko 1). Johtajina ja ylimpinä virkamiehinä työskentelee useampi Nosteen kohderyhmään kuuluvista kuin vähintään toisen asteen tutkinnon suorittaneista. Sen sijaan asiantuntijoina toimivat useammin korkeammin koulutetut (38 \%) kuin perusasteen tutkinnon suorittaneet (13\%). Toimisto- ja asiakaspalvelualoilla, palvelu-, myynti-, ja hoitotyön ammateissa työskentelee 16 prosenttia 30-54vuotiaista riippumatta siitä, onko toisen asteen tutkinto suoritettu vai ei. Rakennus-, korjaus-, prosessi- ja korjaustyöntekijöinä toimii joka neljäs Nosteen kohderyhmään kuuluvista, ja 16 prosenttia korkeammin koulutetuista. Samoin maaja metsätalouden parissa työskentelee enemmän perusasteen tutkinnon suorittaneita verrattuna korkeammin koulutettuihin. Pääasiallisen toiminnan ja ammattirakenteen tarkastelun perusteella voidaan todeta, ettei ole olemassa sellaista stereotyyppistä vailla toisen asteen tutkintoa olevien joukkoa, joka koostuisi enimmäkseen tiettyjen ammattiryhmien edustajista.

\section{NOSTE-OHJELMAN KOHDERYHMÄ JA KOULUTUS}

\section{Aikaisemmat opinnot}

Enemmistö (77 \%) Noste-ohjelman kohderyhmään kuuluvasta on suorittanut kansa- tai kansalaiskoulun. Kohderyhmään kuuluvien
AKU2000 -haastattelussa mainitsemat muut aikaisemmat opinnot on esitetty taulukossa 2 . Koulutukseksi on laskettu kaikki Suomessa tapahtunut opiskelu, joka on kestänyt yhteensä vähintään kuusi tuntia. Aikuiskoulutuksen kesto on vaihdellut koulutukseen osallistuneilla aikuisilla: yli puolet on ollut koulutuksessa 1-5 päivää, neljäsosa 6-20 päivää, ja viidesosa sitä pidempään.

Haastattelua edeltäneen vuoden aikana työpaikalla järjestettyyn työnantajan tarjoamaan koulutukseen on osallistunut joka viides, ja konferenssiin tai seminaariin joka kymmenes Nosteohjelman kohderyhmään kuuluvista. Yhteensä kaksi kolmasosaa on ollut mukana työnantajan järjestämässä koulutuksessa. Konferensseihin ja seminaareihin on työuransa aikana osallistunut joka kolmas. Kansalaisopistossa on opiskellut reilu kolmannes kohderyhmään kuuluvista. Erilaisten järjestöjen, liittojen ja yhdistysten järjestämään koulutukseen on osallistunut kaikkiaan lähes neljännes, ja täydennyskoulutukseen sitäkin useampi Noste-ohjelman kohderyhmästä. Ammatillisten oppilaitosten järjestämään koulutukseen on osallistunut yhteensä yli kolmannes kohdejoukkoon kuuluvista. Lisäksi joka kymmenes Noste-ohjelman kohdejoukkoon kuuluvista ilmoittaa opiskelleensa aikuislukiossa. Lukio- tai ammatilliset opinnot eivät näy tutkintorekisterissä, koska koulutuksia ei ole suoritettu loppuun tai ne eivät muuten ole täyttäneet sillä hetkellä voimassa olevaa toisen asteen tutkinnon määritelmää.

Enintään perusasteen tutkinnon suorittaneilla aikuisilla on varsin runsaasti erilaisia kokemuksia koulutuksesta. Koulutustason kohottamisohjelman kohdejoukon keski- ja korkea-asteen tutkinnon suorittaneita vähäisempi kiinnostus osallistua aikuiskoulutukseen ei taulukkoon 2 koottujen tulosten perusteella voi johtua yksinomaan peruskoulun jälkeisten koulutuskokemusten puuttumisesta (Kokkila 2003). AKU2000 -aineistosta ei kuitenkaan selviä millaisia kokemuksia, myönteisiä vai kielteisiä, kohderyhmällä on koulutuksesta.

\section{Aikuiskoulutukseen osallistuminen}

Aikuiskoulutustutkimus 2000 -aineiston työlliseen työvoimaan kuuluvien 30-54-vuotiaiden aikuisten osallistuminen aikuiskoulutukseen vaihtelee selvästi koulutusasteen mukaan, mutta osallistumisaste on kaiken kaikkiaan erittäin korkea. Joskus työuransa aikana aikuiskoulutukseen on 


\begin{tabular}{|c|c|c|c|}
\hline Koulutus* & $\begin{array}{l}\text { Osallistunut } \\
\text { koulutukseen } \\
12 \text { kk:n aikana (\%) }\end{array}$ & $\begin{array}{l}\text { Osallistunut } \\
\text { koulutukseen } \\
\text { aikaisemmin (\%) }\end{array}$ & $\begin{array}{l}\text { Koulutukseen } \\
\text { osallistuneet } \\
\text { yhteensä (\%) }\end{array}$ \\
\hline \multicolumn{4}{|l|}{ työnantajan järjestämä koulutus } \\
\hline työpaikalla** & 21 & 41 & 63 \\
\hline kansalais- tai työväenopisto** & 7 & 33 & 40 \\
\hline $\begin{array}{l}\text { konferenssi tai seminaari** } \\
\text { täydennyskoulutusta antavan }\end{array}$ & 11 & 22 & 33 \\
\hline koulutusyksikön kurssi** & 9 & 20 & 29 \\
\hline järjestö, liitto, tai yhdistys** & 4 & 19 & 24 \\
\hline $\begin{array}{l}\text { työvoimapoliittinen koulutus** } \\
\text { ammatillinen oppilaitos, }\end{array}$ & 5 & 15 & 20 \\
\hline aikuiskoulutus** & 6 & 13 & 19 \\
\hline ammatillinen oppilaitos, nuorisoaste & - & 17 & 17 \\
\hline oppisopimuskoulutus** & 1 & 9 & 9 \\
\hline $\begin{array}{l}\text { kirjeopisto/kielikoulu** tai opetus- } \\
\text { ohjelmasarja (radio/TV) } \\
\text { opintokeskus**. kansanopisto tai }\end{array}$ & 2 & 21 & 23 \\
\hline $\begin{array}{l}\text { kansankorkeakoulu } \\
\text { kesäyliopisto**, yliopisto tai }\end{array}$ & 1 & 10 & 11 \\
\hline korkeakoulu & - & 4 & 4 \\
\hline iltalukio** & 1 & 4 & 4 \\
\hline konekirjoitus tai tekstinkäsittelykoulu & - & 12 & 12 \\
\hline
\end{tabular}

osallistunut korkea-asteen tutkinnon suorittaneista 99 prosenttia, keskiasteen tutkinnon suorittaneista 98 prosenttia, ja enintään perusasteen tutkinnon suorittaneista yhteensä 92 prosenttia. Vailla toisen asteen tutkintoa olevat naiset (96\%) ovat osallistuneet miehiä (90 \%) useammin aikuiskoulutukseen. Sama tulos koulutuksen kasautumisesta on saatu myös useissa aikaisemmissa empiirisissä aikuisten koulutusta koskevissa tutkimuksissa (esim. Blomqvist, Ruuskanen, Niemi \& Nyyssönen 2002; Silvennoinen \& Aaltonen 1999).

Vähiten koulutukseen ovat osallistuneet Noste-ohjelman kohderyhmään kuuluvat miehet, joista joka kymmenes ei ole koskaan osallistunut aikuiskoulutukseen. Tämä ryhmä on Noste-ohjelman kannalta haaste, koska esimerkiksi ruotsalaisten miesten koulutukseen osallistumista ja osallistumattomuutta koskevat tutkimustulokset osoittavat, että aikaisemmat opinnot ennustavat merkittävästi myös myöhempää koulutukseen osallistumista. Toisin sanoen koulutukseen osal- listuivat ne miehet, joilla koulutusta oli entuudestaan. (Tuijnman 1989, 149-163.)

Kun tarkastellaan erikseen työhön tai ammattiin liittyvää aikuiskoulutusta, Noste-ohjelman kohderyhmän miehistä 79 ja naisista 85 prosenttia ilmoitti osallistuneensa joskus koulutukseen. Yhteensä 17 prosenttia kohderyhmään kuuluvista ilmoitti, ettei ollut koskaan osallistunut työhön tai ammattiin liittyvään aikuiskoulutukseen. Toisaalta niillä aikuisilla, jotka ilmoittivat osallistuneensa koulutukseen, oli varsin runsaasti koulutuskokemuksia. Työhön tai ammattiin liittyvään koulutukseen osallistuneista lähes kolmasosa on osallistunut koulutukseen 4-10 kertaa ja kolmasosa yli kymmenen kertaa.

\section{OSALLISTUMISEN SYYT, EDUT JA ESTEET}

AKU2000 -haastattelua edeltäneen kahdentoista kuukauden aikana aikuiskoulutukseen osallistuneilta kysyttiin valmiiden vastausvaihtoehto- 
jen avulla sitä, miksi ja kenen aloitteesta he osallistuivat koulutukseen. Yleisin osallistumissyy oli itsensä tai ammattitaidon kehittäminen (38 \%). Myös Nikkasen (2002, 113-122) tekemän tutkimuksen mukaan yli 40-vuotiaiden aikuiskoulutuskeskuksissa ja oppisopimuskoulutuksessa opiskelevien suurimpia koulutukseen hakeutumisen yleisimpiä syitä olivat halu oppia uusia asioita ja itsensä sekä ammattitaidon kehittäminen. Muita osallistumisen syitä olivat työnantajan velvoite (32 \%) sekä työtehtävien nopea kehittyminen (22 \%). Halu saada uusi ammatti, työttömyys tai sen uhka, oman yrityksen suunnittelu ja uralla eteneminen eivät olleet Noste-ohjelman kohdejoukon vastausten perusteella merkittäviä koulutukseen osallistumisen syitä. Miesten ja naisten vastauksissa oli eroja: miehillä yleisin osallistumissyy oli työnantajan velvoite (35\%), ja naisilla yleisin syy oli itsensä tai oman ammattitaidon kehittäminen (49\%).

Koulutukseen osallistutaan useimmiten työnantajan aloitteesta (59 \%). Myös IALS -aineiston pohjalta tehdyn yli 40-vuotiaiden aikuiskoulutukseen osallistumista käsittelevän tutkimuksen mukaan aloitteentekijä oli useimmiten työnantaja (Linnakylä \& Malin 2000, 213). ${ }^{5}$ Joka kolmas Noste-ohjelman kohderyhmään kuuluvista on osallistunut koulutukseen omasta aloitteestaan. Naiset (45 \%) ovat selvästi miehiä (29 \%) omaaloitteisempia osallistumaan koulutukseen. Tulos on merkittävä Noste-ohjelman kannalta, sillä Nosteessa koulutus toteutetaan omaehtoisena koulutuksena, jonka opiskelija itse valitsee. Koulu- tus on opiskelijalle maksutonta, mutta se ei ole työajalla toteutettavaa tai työnantajan aloitteesta tapahtuvaa henkilöstökoulutusta. Koulutukseen käytetty aika on pääsääntöisesti opiskelijan omaa aikaa. Tosin oppisopimuskoulutuksessa koulutus voi tapahtua Noste-ohjelman puitteissakin suurelta osin työaikana, mikäli näin sovitaan. (Suomalainen 2003.)

Koulutuksen avulla saavutettuja etuja kysyttiin AKU2000 -haastattelussa valmiiden vastausvaihtoehtojen avulla (taulukko 3). Koulutukseen osallistumalla lähes joka toinen sai uusia (49 \%) tai vaativampia (45 \%) työtehtäviä, ja palkka nousi keskimäärin joka kolmannella koulutukseen osallistuneella. Vähiten koulutuksella näyttää olevan vaikutusta työpaikan vaihtoon: viidennes koulutukseen osallistuneista on ilmoituksensa mukaan vaihtanut työpaikkaa koulutuksen johdosta. Koulutukseen osallistumisesta on ollut enemmän suoranaista hyötyä tutkimusjoukon miehille kuin naisille. Miehistä 44 ja naisista 22 prosenttia sai koulutuksen avulla lisää palkkaa. Miehet saivat myös koulutukseen osallistumisen jälkeen uusia työtehtäviä selvästi naisia useammin. Koulutukseen osallistuminen takasi miehille naisia useammin myös vaativampia työtehtäviä, työpaikan tai ammatin vaihtumisen sekä työpaikan säilymisen. Vakituisen työpaikan saamisessa koulutuksesta oli apua noin neljäsosalle tutkimusjoukon miehistä ja naisista. Naiset ilmoittivat miehiä useammin koulutukseen osallistumisella olevan muita vaikutuksia. Aineiston perusteella ei selviä, mitä mainitut "muut vaikutukset” olivat.

Taulukko 3. Työhön tai ammattiin liittyvän koulutuksen tuomat edut 30-54-vuotiaille enintään perusasteen tutkinnon suorittaneille palkansaajille $(n=252)$ sukupuolittain (\%). Taulukossa on käytetty korotuspainoa.

\section{Koulutuksen avulla...}

...lisää palkkaa ***

...sai uusia työtehtäviä $* * *$

...sai vaativampia työtehtäviä *

...vaihtoi työpaikkaa tai ammattia*

...säilytti työpaikkansa*

...auttoi vakituisen työpaikan saamisessa

...muita vaikutuksia *

Yhteensä (N)

$* * * \mathrm{p}<.000$

Miehet (\%)
$\mathbf{n}=\mathbf{1 4 9}$
44
59
51
24
46
25
23

163000

$* * \mathrm{p}<.01$

$\begin{array}{ll}\text { Naiset (\%) } & \text { Yhteensä (\%) } \\ \mathbf{n = 1 0 3} & \begin{array}{l}\boldsymbol{n}=\mathbf{2 5 2} \\ 22\end{array} \\ 35 \\ 36 & 49 \\ 36 & 42 \\ 12 & 19 \\ 33 & 40 \\ 23 & 24 \\ 31 & 26\end{array}$

118000

281000 
Palkansaajilta kysyttiin AKU2000 -haastattelussa henkilöstökoulutukseen osallistumisen esteitä kahdella tapaa. Vastaajia pyydettiin ensiksi arvioimaan valmiiden vastausvaihtoehtojen pohjalta, miten paljon tietyt tekijät ovat osallistumisen esteenä sekä toiseksi nimeämään eniten osallistumista estävä tekijä. Suurimmaksi osallistumisen esteeksi nousee koulutuksen heikko laatu, kun yhdistetään paljon ja jonkin verran esteitä aiheuttaneet tekijät (kuvio 1). Aineiston perusteella ei ole mahdollista selvittää, mihin koulutuksen laadulla on tässä yhteydessä viitattu. Laatu voi liittyä esimerkiksi kouluttajaan, koulutusjärjestelyihin, tai koulutuksen sisältöön. AKU2000 -aineistosta ei käy myöskään ilmi sitä, perustuuko vastaajien arvio tulevan koulutuksen heikosta laadusta heidän omiin aikaisempiin koulutuskokemuksiinsa. Muita merkittäviä osallistumista estäneitä tekijöitä ovat kiireet työpaikalla ja työnantajan järjestämän koulutuksen puute. Kun tarkastellaan yksinomaan paljon koulutukseen osallistumista haitanneita tekijöitä, niin kiireet työpaikalla (21 \%) ja työnantajan järjestämän koulutuksen puute (16\%) ovat suurimmat osallistumisen esteet.

Kun vastaajilta kysyttiin suurinta yksittäistä osallistumisen estettä, niin ainoastaan 3 prosenttia vastaajista piti koulutuksen heikkoa laatua kaikkein suurimpana esteenä koulutukseen osallistumiselle. Kiireet työpaikalla mainittiin sen si- jaan kysymysmuodosta riippumatta eniten osallistumista estävänä tekijänä. Myös IALS -aineiston perusteella tehdyssä tutkimuksessa yli 40 vuotiaiden suurimpia koulutukseen osallistumisen esteitä olivat ajanpuute joka kolmannella ja sopivan koulutuksen puute sekä työkiireet joka viidennellä vastaajalla (Linnakylä \& Malin 2002, 222).

Opetusministeriön Noste-ohjelman toteuttamista ja kohderyhmän valintaa perustellaan ryhmän alhaisemman koulutukseen osallistumisasteen lisäksi epäonnistumisen pelolla, joka tekstin mukaan estää kohderyhmää osallistumasta koulutukseen (Opetusministeriö 2003b, 2). Kuitenkin AKU2000 -haastatteluissa kohderyhmään kuuluvista henkilöistä ainoastaan 4 prosenttia piti epäonnistumisen pelkoa paljon tai jonkin verran osallistumista estävänä tekijänä. Pelko epäonnistumisesta oli kaikkein suurin osallistumista estävä tekijä ainoastaan alle prosentilla $(0,4 \%)$ Noste-ohjelman kohderyhmään kuuluvista.

\section{Osallistumisaikomukset ja koulutukseen asennoituminen}

Noste-ohjelman kohderyhmään kuuluvista hieman alle puolet (46\%) aikoo osallistua aikuiskoulutukseen haastattelua seuraavan vuoden aikana. Erot koulutukseen osallistumisaikomuksissa ovat 30-54-vuotiaiden perus-, keski- ja korkea-

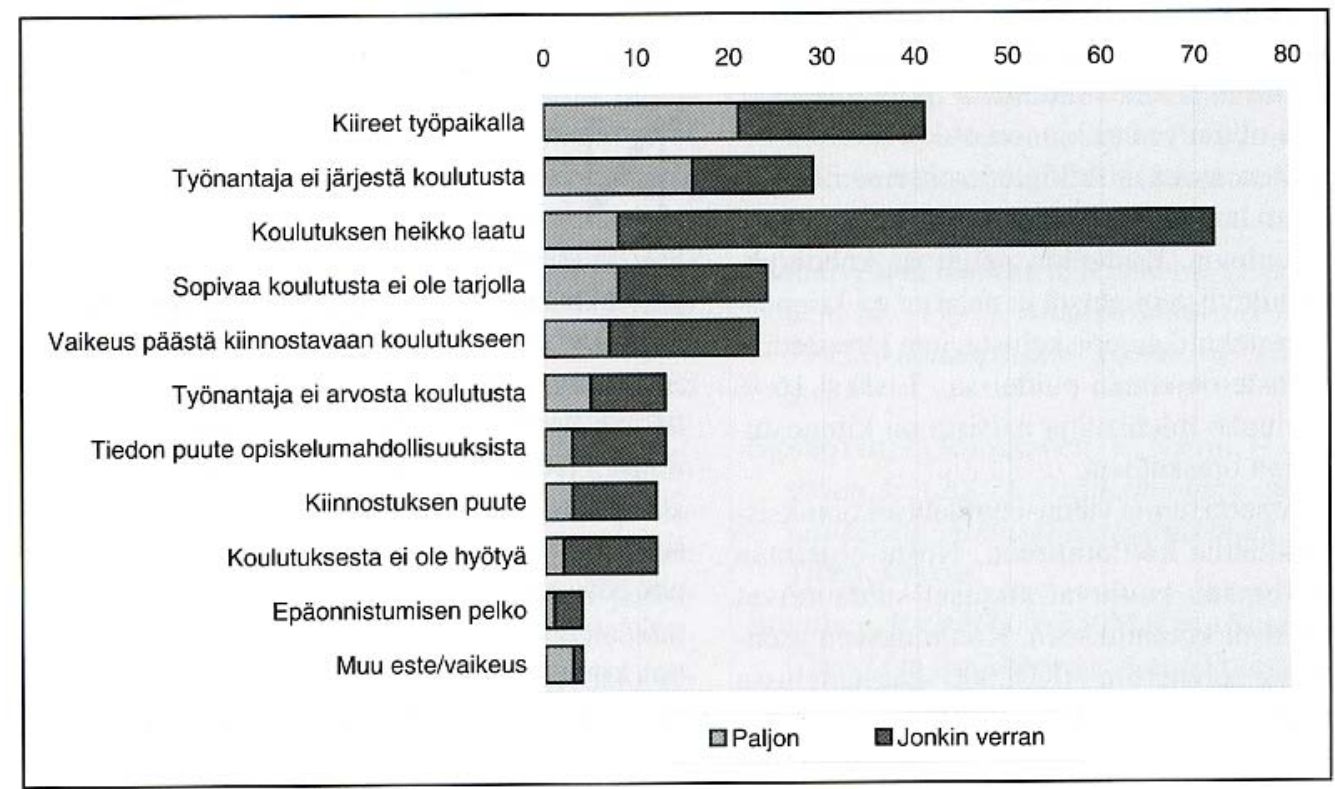

Kuvio 1. Henkilöstökoulutukseen osallistumisen esteet työlliseen työvoimaan kuuluvilla vailla toisen asteen tutkintoa olevilla 30-54-vuotiailla palkansaajilla (n=242) (\%). Kuviossa on käytetty korotuspainoa. 
asteen tutkinnon suorittaneiden välillä selviä. Eniten koulutukseen aikovat osallistua korkeaasteen tutkinnon suorittaneet naiset (84 \%) ja vähiten perusasteen tutkinnon suorittaneet miehet (39 \%). Tutkintoon johtavaan koulutukseen osallistumisaikomukset ovat vähäisiä kaikilla aineiston 30-54-vuotiailla. Osallistumisaikomus vaihtelee kuitenkin koulutusasteittain siten, että eniten koulutukseen aikovat osallistua korkeaasteen tutkinnon suorittaneet naiset (12\%) ja vähiten Noste-ohjelman kohderyhmään kuuluvat miehet, joista kukaan ei Aikuiskoulutustutkimus 2000 -haastattelussa ilmoittanut aikovansa osallistua tutkintoon johtavaan koulutukseen. Kohderyhmän naisista 6 prosenttia aikoi osallistua tutkintoon johtavaan koulutukseen haastattelua seuraavan kahden vuoden aikana. Eniten osallistumisaikomuksia sekä aikuiskoulutukseen että tutkintoon johtavaan koulutukseen on niillä, joilla koulutusta ja tutkinto on jo aikaisemmin.

Tutkintotavoitteinen koulutus määritellään AKU2000 -aineistossa hieman eri tavoin kuin Noste-ohjelmassa, joten todellisuudessa kohdejoukon näkemykset tutkintoon johtavasta koulutuksesta eivät poikkea näin jyrkästi Noste-ohjelman tavoitteista. AKU2000 -aineistossa tutkintotavoitteisella koulutuksella tarkoitetaan vähintään lukuvuoden mittaisia opintoja, jotka tuottavat muodollisen tutkinnon. Noste-ohjelmassa tutkintotavoitteisella koulutuksella puolestaan tarkoitetaan ammatillista perustutkintoa, ammattitutkintoa tai erikoisammattitutkintoa sekä niiden osaa tai osia. Noste-ohjelmassa tutkintotavoitteinen koulutus ei siis välttämättä tuota tutkintoa, vaan voi olla myös tutkinnon osa.

Tulosten mukaan tutkintotavoitteinen koulutus ei juuri houkuttele Noste-ohjelman kohderyhmään kuuluvia. Kuitenkin neljäsosa kohderyhmään kuuluvista miehistä ja naisista on kiinnostunut tietotekniikan opiskelusta, jota järjestetään myös Noste-ohjelman puitteissa. Lisäksi $16 \%$ kohderyhmän miehistä ja naisista on kiinnostunut kielten opiskelusta.

Huolimatta muita vähäisemmistä aikomuksistaan osallistua koulutukseen, Noste-ohjelman kohderyhmään kuuluvat aikuiset suhtautuivat myönteisesti koulutukseen. Koulutukseen asennoitumista selvitettiin AKU2000 -haastattelussa koulutusta koskevien asenneväittämien avulla. Lähes kaikki vastaajat (87 \%) pitivät koulutusta yhteiskunnan peruspilarina ja uskoivat hyvän koulutuksen auttavan työnsaannissa (93\%).
Kahden kolmasosan mielestä väite Mitä parempi koulutus, sitä varmempi työpaikka pitää paikkansa, ja yli kolmasosan mielestä tutkinto on osoitus hyvästä ammattitaidosta. Suurin osa vastaajista (92 \%) arvioi lisäksi koulutuksen lisäävän itseluottamusta. Perusasteen tai vähemmän suorittaneiden aikuisten näkemykset koulutuksesta ja sen vaikutuksista ovat yleisellä tasolla varsin optimistisia. Sen sijaan väitteen Työelämässä pärjää vain pitkälle koulutettu kanssa täysin tai jokseenkin samaa mieltä oli neljäsosa kohderyhmän vastaajista. Korkeammin koulutetuista vastaajista selvästi harvempi, ainoastaan 15 prosenttia yhtyi edelliseen väitteeseen. Yleisellä tasolla Nosteen kohderyhmään kuuluvat aikuiset suhtautuvat korkeammin koulutettuja myönteisemmin aikuiskoulutukseen, vaikka heillä itsellään ei välttämättä ole aikomuksia osallistua koulutukseen.

Tutkiessaan tanskalaisia vähän koulutettuja ja työttömiä aikuisia Illeris (2003) on todennut näiden aikuisten suhtautuvan koulutukseen ambivalentisti: toisaalta aikuiset uskovat lujasti koulutuksen positiivisiin vaikutuksiin, mutta toisaalta enemmistö tutkimuksen kohteena olleista aikuisista osallistui koulutukseen ainoastaan ulkoisen pakon alla. Tämä tutkimustulos haastaa perinteisen aikuiskoulutuksen ideaalin sisäisesti motivoituneista aikuisopiskelijoista (esim. Knowles 1975).

\section{KOHTI AIKUISTEN KOULUTUS- TASON KOHOTTAMISTA?}

$\mathrm{N}$

Toste-ohjelman tavoitteena on luoda vailla perusasteen jälkeistä tutkintoa oleville aikuisille uusia koulutusmahdollisuuksia, joiden avulla he voivat toteuttaa elinikäisen oppimisen periaatteita. Tässä artikkelissa olen tarkastellut Noste-ohjelman kohderyhmää enimmäkseen suunnittelu- ja valmisteluasiakirjojen (Opetusministeriö 2002; 2003b; 2004), asetusten (A41/ 2003; A35/2004) sekä Aikuiskoulutustutkimus 2000 -aineiston avulla. AKU2000 -aineiston perusteella kohderyhmä on heterogeeninen joukko niin pääasiallisen toiminnan kuin ammatin mukaan tarkasteltuna. Nosteen kohderyhmä on osallistunut koulutukseen korkeammin koulutettuja vähemmän, ja sillä on myös vähemmän aikomuksia osallistua aikuiskoulutukseen. Alhaisemmasta osallistumisaktiivisuudestaan huolimatta kohderyhmään kuuluvilla on varsin runsaasti aikaisem- 
pia kokemuksia aikuiskoulutuksesta. Lisäksi kohderyhmän näkemykset koulutuksesta ja sen vaikutuksista ovat yleisellä tasolla myönteisiä. Koulutuksesta nähdään olevan hyötyä työelämässä, mutta sitä ei välttämättä mielletä omaan elämään sopivaksi. Tämä ristiriita kohderyhmän yleisen asennoitumisen ja oman käyttäytymisen välillä muodostaa haasteen Noste-ohjelmalle ja sen puitteissa toteutetuille opintoihin hakeutumista edistäville toimille.

Noste-ohjelmaan sisältyvät opintoihin hakeutumista edistävät toimet kuten hakeva toiminta, tiedotus ja neuvonta sekä opiskelun tukitoimet vastaavat Kunskapslyftetin tulosta siitä, että julkisella tuella on suuri vaikutus niiden aikuisten koulutukseen osallistumiseen, joiden osallistumisaste muuten on alhaisin (Tuijnman \& Hellström 2001). Noste-ohjelman luonnoksessa (Opetusministeriö 2003b) hakevaa toimintaa ja opiskelun tukitoimia perustellaan kohdejoukon vähäisemmällä koulutukseen osallistumisella ja epäonnistumisen pelolla. AKU2000 -aineiston mukaan pelko epäonnistumisesta oli kuitenkin kaikkein vähiten kohdejoukon osallistumista estänyt tekijä.

Koulutukseen osallistumisen merkittävimmiksi esteiksi nimettiin tiedon puute, koulutukseen pääsyn vaikeus, työnantajan järjestämän tai muuten sopivan koulutuksen puute ja koulutuksen heikko laatu. Näihin edellä mainittuihin osallistumisen esteisiin voidaan vaikuttaa myös Nosteohjelmalla. Tiedon puute on yksi mainituista osallistumisen esteistä, joita ohjelma pyrkii korjaamaan. Myös koulutukseen pääsy saattaa ohjelman myötä helpottua. Lisäksi Noste-ohjelma voi tarjota sopivaa koulutusta, tai korvata työnantajan järjestämän koulutuksen puutteen, sillä opiskelu ohjelmassa on osallistujille ilmaista ja oppiminen pyritään pitämään mahdollisimman lähellä käytäntöä ja työelämää. Koulutuksen työelämälähtöisyyden lisäksi tutkintojen tai niiden osien suorittaminen (Opetusministeriö 2003b, 4-5; Opetusministeriö 2002, 16-17) sekä tietoyhteiskuntavalmiuksia lisäävä koulutus (A41/2003; Opetusministeriö 2002, 16) korostuvat Noste-ohjelman asiakirjateksteissä. AKU2000-aineiston perusteella kohderyhmän miehet ja naiset ovat huomattavasti kiinnostuneempia osallistumaan tietotekniikkakoulutukseen kuin tutkintoon johtavaa koulutukseen.

Aikaisempien vastaavia ohjelmia koskevien tutkimustulosten mukaan aikuisilla on taipumus opiskella tosissaan vain sellaisia asioita, joista he katsovat olevan itselleen hyötyä (Illeris 2003; Paldanius 2002). Tämä asettaa haasteen Nosteohjelmalle, koska aikuisten puolesta ei voida päättää mitä koulutusta he tarvitsevat, vaan koulutuksen tarpeen on lähdettävä aikuisista itsestään (Antikainen 2003b). Suunnittelu- ja valmisteluasiakirjoissa Noste-ohjelman kohdejoukosta puhutaan laskennallisena ja varsin yhtenäisenä 330000 ihmisen ryhmänä. AKU2000-aineiston valossa kohdejoukko näyttää hyvin heterogeeniseltä ja monenlaisia koulutuskokemuksia omaavalta ryhmältä, jota yhdistää muodollisen tutkinnon puuttuminen. Kohdejoukosta löytyy runsaasti ammattitaitoa ja työkokemusta, mutta ainakaan toistaiseksi omaa osaamista ei ole osoitettu suorittamalla tutkintoa.

\section{LÄHTEET}

A41/2003. Valtioneuvoston asetus aikuisten koulutustason kohottamiseen myönnettävästä valtionavustuksesta. Helsinki.

A35/2004. Valtioneuvoston asetus aikuisten koulutustason kohottamiseen myönnettävästä valtionavustuksesta. Helsinki.

Ahola, J. (2002). Aikuisten koulutustason kohottamisohjelma käynnistymässä. Ammatinvalinnanohjauksen vuosikirja 2002, 5-10. Helsinki: Työministeriö.

Antikainen, A. (2003a). Noste-ohjelma on koulutuspoliittinen avaus. Aikuiskasvatus 2, 150-151.

Antikainen, A. (2003b). Noste-ohjelma tutkimuksen kohteena. Nostetta Pohjois-Karjalaan -seminaari 8.10.2003. Joensuu: PohjoisKarjalan Aikuisopisto.

Blomqvist, I., Koskinen, R., Niemi, H. \& Simpanen, M. (1997). Aikuiskoulutustutkimus 1995. Aikuisopiskelu Suomessa. Tilastokeskus.

Blomqvist, I., Ruuskanen, T., Niemi, H. \& Nyyssönen, E. (2002). Osallistuminen aikuiskoulutukseen. Aikuiskoulutustutkimus 2000. Tilastokeskus.

Bourdieu, P. (1997). What Makes a Social Class? On the Theoretical and Practical Existence of Groups. Berkeley Journal of Sociology 32, 1-17.

Illeris, K. (2003). Adult Education as Experienced by the Learners. Lifelong Education 22, 13-23. 
Knowles, M. S. (1975). Self-Directed Learning. Englewood Cliffs, NJ: Prentice Hall.

Kokkila, H. (2003). Elinikäiseksi oppijaksi aikuisiällä? Vailla toisen asteen tutkintoa olevien 30-54-vuotiaiden osallistuminen aikuiskoulutukseen ja käsitykset koulutuksen tarpeesta. Joensuun yliopiston sosiologian laitoksen raportteja 1 .

Kurkela, R. \& Sauli, H. (1998). Tilastolliset luokitukset ja arki. Teoksessa Paananen, S., Juntto, A. \& Sauli, H. (toim.) Faktajuttu. Tilastollisen sosiaalitutkimuksen käytännöt, 2743. Vastapaino.

Linnakylä, P. \& Malin, A. (2002). Yli 40-vuotiaat aikuiskoulutuksessa: Aikuiskoulutukseen osallistuminen ja siitä syrjäytyminen SIALS -aineiston valossa. Teoksessa Stenström, M-L., Linnakylä, P., Malin, A., Nikkanen, P., Piesanen, E. \& Valkonen, S. (2002). Yli 40vuotiaat aikuiskoulutuksessa: "Kyllä sieltä aina jotain reppuun jää!”,171-236. Opetusministeriö, koulutus- ja tiedepolitiikan osasto.

Linnakylä, P., Malin, A., Sulkunen, S., Blomqvist, I. \& Virtanen, H. (2000). Lukutaito työssä ja arjessa: Tiedote 15.6.2000. http:// www.jyu.fi/ktl/sials/tied1506a.htm 17.8.2003.

Moore, E. (2002). Osallistuu - ei osallistu. Osallistumattomuus aikuiskoulutuksen haasteena. Ammatinvalinnanohjauksen vuosikirja 2002, 19-29. Työministeriö.

Nikkanen, P. (2002). Aikuisopiskelijoiden tarpeita, kokemuksia ja odotuksia kolmesta erityyppisestä aikuiskoulutuksesta. Teoksessa Stenström, M-L., Linnakylä, P., Malin, A., Nikkanen, P., Piesanen, E. \& Valkonen, S. (2002). Yli 40-vuotiaat aikuiskoulutuksessa: "Kyllä sieltä aina jotain reppuun jää!”, 105-170. Helsinki: Opetusministeriö, koulutus- ja tiedepolitiikan osasto.

OECD \& Statistics Canada (2000). Literacy in the Information Age. Final Report of the International Adult Literacy Survey. OECD.

Opetusministeriö (2002). Parlamentaarisen aikuiskoulutustyöryhmän mietintö 3:2002. http://www.minedu.fi/julkaisut/julkaisusarjat/ 3parlam_aikkoultr/3kuvailu.html 11.9.2002.

Opetusministeriö (2003a). Valtionavusta aikuisten koulutustason kohottamiseen. http:/ /www.minedu.fi/opm/uutiset/archive/2003/ 01/23_1.html 27.1.2003.
Opetusministeriö (2003b). Noste-ohjelma 20032007. Aikuisten koulutustason kohottamisohjelman toimeenpano ja rahoitus opetusministeriön hallinnonalalla. Luonnos 14.2.2003.

Opetusministeriö (2004). Valtioneuvoston asetus aikuisten koulutustason kohottamiseen myönnettävästä valtionavustuksesta. Muistio 8.1.2004.

Paldanius, S. (2002). Ointressets rationalitet: Om svårigheter att rekrytera arbetslösä till vuxenstudier. Lindköping studies in education and psychology 86.

Rubenson, K. (2001). The Swedish Adult Education Initiative: From Recurrent Education to Lifelong Learning. In Aspin, D. et al. (eds.) International Handbook of Lifelong Learning. Dordrecht: Kluwer.

Silvennoinen, H. \& Aaltonen, S. (1999). Työ ja koulutustarve. Opetusministeriö, koulutusja tiedepolitiikan osasto.

Simpanen, M. (1993). Aikuiskoulutustutkimus 1990. Aikuiskoulutus ja työelämä. Tilastokeskuksen tutkimuksia 201. Tilastokeskus.

Suomalainen, H. (2003). Aikuisten ammattitutkinto kohentaa työllistymistä. Sanomalehti Karjalainen 27.7.2003.

Tilastokeskus (2003). Tutkintorekisteri. http:// www.stat.fi/tk/tp/rekisteriseloste_tutkintorekisteri.html 18.8.2003.

Tuijnman, A. (1989). Recurrent Education, Earn-ings, and Well-being. A Fifty-Year longitudinal Study of a Cohort of Swedish Men. Acta Universitatis Stockholmiensis. Stocholm Studies in Educational Psychology 24. Stocholm: Almqvist \& Wiksell International.

Tuijnman, A. \& Hellström, Z. (toim.) (2001). Curious Minds: Nordic Adult Education Compared. Nordic Council.

Walsh, A. (1990). Statistics for Social Sciences: With Computer Applications. New York: Harper\&Row.

\section{VIITTEET}

1. Artikkeli perustuu keväällä 2003 valmistuneeseen pro gradu - tutkielmaani ”Elinikäiseksi oppijaksi aikuisiällä? Vailla toisen asteen tut- 
kintoa olevien 30-54-vuotiaiden osallistuminen aikuiskoulutukseen ja käsitykset koulutuksen tarpeesta.” Tutkielma on julkaistu Joensuun yliopiston raportteja sarjassa, ja on saatavissa internetistä osoitteesta: http://www.nosteohjelma.fi/fin/bitmap.asp? R=154

2. AKU2000-aineiston "Noste-ohjelman kohderyhmään” kuuluvat henkilöt olivat haastatteluhetkellä (vuonna 2000) 30-54-vuotiaita. Jos kohderyhmäksi haluttaisiin täsmälleen sama 30-54vuotiaiden henkilöiden ryhmä, jotka vuonna 2003 olivat oikeutettuja Noste-ohjelmaan, kohderyhmä muodostuisi AKU -aineiston 27-51-vuotiaista henkilöistä.

3. Iän, koulutuksen ja asuinmaakunnan mukaisia pieniä eroja on aineistossa korjattu painokertoimien avulla. Painokertoimet on laskettu kalibrointimenetelmän avulla, jossa käytetään hyväksi perusjoukon reunajakaumia koskevia tietoja. Kalibroinnissa otoksesta laskettavat jakaumat saadaan vastaamaan perusjoukon reunajakaumia. Menetelmässä käytettiin seuraavia muuttujaryhmittelyjä: 1) ikäluokka ja ISCED -aste (=koulutustaso), 2) sukupuoli ja maakunta. (Blomqvist, Ruuskanen, Niemi \& Nyyssönen 2002, 134135.)
4. Tutkintorekisterin perustana ovat vuoden 1970 väestönlaskennassa kerätyt tutkintotiedot, jolloin tutkinnoiksi määriteltiin ylioppilastutkinnot, vähintään kuusi kuukautta kestäneet ammatilliset koulut, opistot tai ammatilliset kurssit, kansanopistot tai kansankorkeakoulut sekä korkeakoulututkinnot. Tätä perusaineistoa on päivitetty vuosittain oppilaitoksista ja muista lähteistä saaduilla tutkintotiedoilla. Vuoden 1990 loppuun asti ammatilliseksi tutkinnoksi katsottiin päivitysaineistossa vähintään 400 tuntia kestänyt ammatillinen koulutus työllisyyskoulutus mukaan lukien. Vuodesta 1991 lähtien on ammatilliseksi tutkinnoksi luettu vain keskiasteen uudistuksessa koulutusammattiin tai tutkintoon johtavaksi määritelty koulutus. Vuodesta 1994, ammattitutkintolain voimaantulosta lähtien, ammatilliseksi tutkinnoksi on katsottu myös näyttötutkintona suoritettu ammatillinen perustutkinto, ammattitutkinto ja erikoisammattitutkinto. (Tilastokeskus 2003.)

5. IALS (The International Adult Literacy Survey) koostuu vuosina 1994, 1996 ja 1998 kerätystä kansainvälisestä aineistosta. IALS tutkimuksen aineisto on kerätty Suomessa vuonna 1998. (Linnakylä, Malin, Sulkunen, Blomqvist \& Virtanen 2000.) 